Abstracta Iranica Abstracta Iranica

Revue bibliographique pour le domaine irano-aryen

Volume 28 | 2007

Comptes rendus des publications de 2005

Don Juan of Persia: A Shi ah Catholic, 1560-1604. London, Routledge Curzon, 2005 (reprinting of 1926 edition), 355 p., index, maps.

Colin Mitchell

(2) OpenEdition

Journals

Édition électronique

URL : http://journals.openedition.org/abstractairanica/17712

DOI : 10.4000/abstractairanica. 17712

ISSN : 1961-960X

Éditeur :

CNRS (UMR 7528 Mondes iraniens et indiens), Éditions de l'IFRI

Édition imprimée

Date de publication : 15 mai 2007

ISSN : 0240-8910

Référence électronique

Colin Mitchell, «Don Juan of Persia: A Shi ah Catholic, 1560-1604. London, Routledge Curzon, 2005 (reprinting of 1926 edition), 355 p., index, maps. », Abstracta Iranica [En ligne], Volume 28 | 2007, document 172, mis en ligne le 18 septembre 2007, consulté le 25 septembre 2020. URL : http:// journals.openedition.org/abstractairanica/17712 ; DOI : https://doi.org/10.4000/abstractairanica 17712

Ce document a été généré automatiquement le 25 septembre 2020.

Tous droits réservés 


\title{
Don Juan of Persia: A Shi' ah Catholic, 1560-1604. London, Routledge Curzon, 2005 (reprinting of 1926 edition), 355 p., index, maps.
}

\author{
Colin Mitchell
}

In 1599, a Persian embassy was organized and dispatched by Šāh 'Abbās I to the Vatican and a number of European imperial courts. A well-known account of this embassy appears in Don Juan of Persia, allegedly written by the Persian secretary Ulug Beg, and often understood as one of the first Persian travel accounts of Europe. This embassy of some 40-50 personages, traveling via the Caspian Sea and Russia, began to fray at the edges as the nominal chief ambassador Husayn 'Alī Beg bickered constantly with the infamous Anthony Sherley over rank and precedence. By the time it reached Rome, the Persian embassy had lost all cogency, and Sherley removed himself to pursue his own unique ambitions in Spain and North Africa. The embassy was diluted further when a number of its members, including Ulug Beg, converted to Catholicism and opted to remain in Spain. Christened as Don Juan, he decided to translate and publish his account for the edification of Spanish society. His confessor, spiritual guide, and mentor, one Alfonso Rémon, "helped" Don Juan in the translation of his journal from Persian to Castilian, and the constant references throughout the text to universal histories and geographies by men like Giovanni Botero and Petrus Amianus, suggests that much of Don Juan's description of Persian provinces and customs are based on Rémon's reading of these sources. Likewise, the presentation of ancient Iranian history is based exclusively on classical historians of antiquity, Strabo, Procopius, Megasthenes, and Nicephorus Callistus, to name a few, and we surmise quickly that this text can hardly be ranked as an authentic "Persian" account. Guy Le Strange, the editor and translator of Don Juan of Persia in the original 1926 edition, qualifies many of Don Juan's "observations", but by and large he seems unfazed by the loose nature of the transmission: Don Juan, with 2-3 years of competency in the Castilian language, 
translated - orally - his journal from Persian into colloquial Castilian, which was then allegedly transcribed at the same time by Rémon, and later published in 1604.

The text is divided into three major parts. The first entails a presentation of chapters on Persian geography, customs, rituals, political structures, as well as Persian and Islamic history from the time of Noah to the advent of the Ottoman state. Don Juan's status as an accurate indigenous source can be called into question immediately in his personal description of Šîāz, a city he claims to have toured frequently. He recounts how "this city was in ancient days called Persepolis" (p. 38), but it is highly improbable that an educated, literate Persian scribe would conflate these two profoundlyimportant, historical spaces which stand some 60 kilometers apart. Perhaps more troubling is his list of demographic statistics for various Iranian cities: Qazvin at 450,000, Yerevān, Astarābād, Māzandarān, at 225,000 each, and Herāt at no less than 4.5 million! Part Two introduces the rise of the Safavid household, and its shi'itization under Ḥaydar and Ismā‘îl, and then continues into a detailed account of the reign of Muhammad Hudābanda and the role of his son, Mīrzā Hamza, in the defense of Iran during the latest incarnation of Ottoman-Safavid hostilities between 1578 and 1590. Don Juan and Rémon base much of this discussion on the eyewitness account of Thomas Minadoi (Venetian author of Historia della Guerra fra Turchi et Persiani), but later add that Minadoi was very "ill-informed" on developments in Hurāsān during this period, and instead rely on the recollections of Don Juan's father, Sulțān 'Alī Beg Bayāt, who had been a figure of great repute and apparently much loved by both Hुudābanda and Mīrzā Hamza. While certainly impressive in its detail, we cannot help but wonder how much of this can be taken at face value, especially when Don Juan narrates how Šāh Hudābanda "ordered a picture [of Don Juan's father] to be painted above the bodies of the seven Turkish commanders whom with his own hand he had slain, and this picture still may be seen placed above the door of one of the Mosques of Tabrìz (p. 193)". The third part consists of a narration of the embassy's travels and experiences as they passed into Russia, through the North Sea on boat, and overland from Saxony through Thuringia to Prague, Rome, Venice, and Spain. Sir Anthony Sherley does not come across especially well in this narrative, especially when Don Juan relates how Sherley fooled the Persian ambassador into transferring the embassy's consignment of gifts to another ship for safekeeping, only to sell these later to English merchants working in Archangel and other Russian ports. Predictably, Don Juan presents his conversion in Valladolid, and those of his colleagues, as part of God's will but this sudden affinity for the Christian faith likely came about at the prospect of having to inform the famouslyintemperate Šāh 'Abbās that a small fortune had been lost.

3 The large number of errors, mischaracterizations, and quotations from both antique and contemporary sources suggest that Don Juan is much more of a compendium of various sources which was then integrated, perhaps a little sloppily, with Don Juan's personal travel account. Interestingly, Le Strange does not include any translations of the preambular texts which first appeared with the Spanish 1604-printing, including a ten page letter to Don Alvario de Caravajal, which describes intriguingly how and why he helped Don Juan translate his Persian travel account into Castilian. 
INDEX

Thèmes : 4.2.1. Safavides et Qâjârs

\section{AUTEURS}

COLIN MITCHELL

Dalhousie University - Halifax 